\title{
Morphological, anatomical, macro and micromolecular markers for Solanum cernuum identification
}

\author{
Tânia Maria Almeida Alves ${ }^{1 *}$, Samanta Marengo ${ }^{1}$, Cristiane Machado ${ }^{1}$, Roberta Caldeira ${ }^{1}$, \\ Omar Carvalho ${ }^{1}$, Rosy Mary dos Santos Isaias', João Renato Stehmann', Carlos Zani ${ }^{1}$ \\ ${ }^{1}$ Instituto René Rachou, FIOCRUZ, Av Augusto de Lima 1715, 30190-002, Belo Horizonte, MG, Brazil, \\ ${ }^{2}$ Departamento de Botânica, Instituto de Ciências Biológicas, Universidade Federal de Minas Gerais, Av Antonio \\ Carlos 6627, Campus da Pampulha, 31270-901, Belo Horizonte, MG, Brazil
}

\begin{abstract}
RESUMO: "Marcadores morfológicos, anatômicos, macro e micromoleculares para a identificação de Solanum cernuum". Plantas consumidas como remédio nem sempre são identificadas taxonomicamente de maneira correta. Se estas plantas forem utilizadas para obtenção de uma droga vegetal ou um fitoterápico, tal erro pode afetar a qualidade do produto final. Neste trabalho são descritos marcadores para a identificação de Solanum cernuum Vell. (Solanaceae), esteja a planta íntegra, triturada ou como extrato bruto. Indivíduos de quatro localidades de Minas Gerais foram coletados, analisados e comparados. Os caracteres morfológicos foram utilizados para a planta íntegra. Para a planta triturada, o conjunto dos tricomas foi utilizado como marcador anatômico. Um marcador macromolecular também foi determinado. Para tal a região ITS1, 5.8S e ITS2 do DNAr foi clonada e seqüenciada. A seqüência, com cerca de 600 pares de bases dos quais $48,1 \%$ são AT, foi depositada no GenBank sob o número de acesso DQ837371. Por ser uma seqüência específica para $S$. cernuum, ela pode ser usada como marcador desta espécie. Para o extrato bruto foram determinados perfis cromatográficos de extratos das folhas por cromatografia em camada delgada e por cromatografia líquida de alta eficiência. Dois flavonóides foram isolados e identificados como quercitrina e afzelina. Assim, neste trabalho foram determinados marcadores morfológicos, anatômicos, macro e micromoleculares para identificar S. cernuum.
\end{abstract}

Unitermos: Solanum cernuum, Solanaceae, tricomas, quercitrina, afzelina, ITS rDNA.

\begin{abstract}
The plants consumed as remedy by the population may have imprecise taxonomical identification. If these plants are used for the production of phytomedicines such misidentification may affect the quality of the product. Hereby, we describe markers for identification of the entire plant or grounded plant material or the crude extract of Solanum cernuum Vell. (Solanaceae). Specimens from four localities were collected, analyzed and compared. Morphological characters were used to identify the plant when it is not grounded or extracted. However, when the plant material is grounded, the set of trichomes may be used as anatomical marker. The region ITS1, $5.8 \mathrm{~S}$ and ITS2 of the nuclear ribosomal DNA was cloned and sequenced. The sequence, with length of about 600 base pairs, being $48.1 \%$ AT , was deposited in GenBank under the accession number DQ837371. Once this sequence is specific to $S$. cernuum, it was used as marker for this species. For the crude extract, chromatographic profiles of the leaves extracts were obtained by thin layer chromatography (TLC) and high performance liquid chromatography (HPLC). Two flavonoids were isolated and identified as quercitrin and afzelin. So, this study presents morphological, anatomical, macro and micromolecular markers to identify S. cernuum.
\end{abstract}

Keywords: Solanum cernuum, Solanaceae, trichomes, quercitrin, afzelin, ITS rDNA.

\section{INTRODUCTION}

The correct botanical identification of plants is one of the steps that will guarantee success of herbal drug technology. Botanical identification is classically based on anatomical and morphological data. However, when the herbal products to be identified are extracts, powder or there are only vegetative plant organs, other tools should be used for identification. Chromatographic techniques to analyze crude extracts, such thin layer chromatography (TLC), high performance liquid chromatography (HPLC) or gas chromatography (GC) hyphenated with detection techniques such as ultraviolet (UV), mass spectrometry (MS) and nuclear magnetic resonance have been successfully employed. For examples see Fan et al. (2006), Borse et al. (2002), Di et al. (2003), Hostettmann and Marston (2002), Yang (2006). Also, DNA-based techniques have been widely used for authentication of medicinal plants especially in the case when those plants are substituted or adulterated with other species morphologically or chemically indistinguishable (Joshi et al., 2004). The internal 
transcribed spacer (ITS) region of $18 \mathrm{~S}-26 \mathrm{~S}$ nuclear ribosomal DNA (nrDNA) has proven to be a powerful tool for phylogenetic studies (Baldwin et al., 1995). According to Hsiao et al. (1994), rDNA ITS of Poaceae have enough variability to distinguish between species. Zhao et al. (2001) used characters of rDNA ITS region to distinguish Alpinia galanga (L.) Sw., a plant used as a traditional Chinese medicine, from related species of Zingiberaceae.

The genus Solanum is the biggest one within the Solanaceae with at least 1000-1200 species (Hunziker, 2001). It is rich in steroidal alkaloids as tomatidine (Takagi et al., 1994) and solasodine (Yencho et al., 1998; Barbosa-Filho et al., 1991; Silva et al., 2005).

Solanum cernuum Vell. is a Brazilian shrub or small tree, restricted to Southwest states of the country (Carvalho, 1995, 1996). The leaves are used freshly or powdered as topical for skin diseases or as depurative and diuretic infusion (Carvalho, 1989). The leaves, entire or grounded, are commercialized as "panacea" mostly without any quality control. Although the extract of this species is not commercialized, it would be important to characterize it once there is no information about its chemistry.

Hereby we describe morphological, anatomical, micro and macromolecular markers of $S$. cernuum with the aim to support the botanical identification of the powdered plant and the crude extract of the leaves.

\section{MATERIAL AND METHODS}

\section{Plant material}

As gold standard, four specimens of $S$. cernuum were collected (Table 1) twice or three times in four different places in the State of Minas Gerais, Brazil, and were identified by Dr JR Stehmann. One voucher was deposited at the herbarium of the Department of Botany, Universidade Federal de Minas Gerais, Brazil under the code BHCB 42855. The voucher from specimen EEUFMG was deposited at same herbarium under the code BHCB 16886.

For TLC profiles comparisons of Solanum tuberosum L. (BHCB 2193), Solanum americanum Mill., Solanum esculentum Dunal (BHCB 56348), Bauhinia curvula Benth. (PAMG 45207) and Ocimum gratissimum L. (BHZB 2106) were used.

\section{Morphological analysis}

Fertile aerial parts of plants were prepared according to usual techniques for herbarium material conservation (Bridson; Forman, 1992). The measurements were made with a Mitutoyo caliper and the observations were done under stereoscopic microscopic Olympus SZH, coupled to an Olympus C-35AS-4 camera.

\section{Anatomical analysis}

To analyze the trichomes distribution, leaves and petioles were embedded in historesin (Reichert Jung) and transversely sectioned in a rotative microtome (Reichert Jung 2035) with a C steal knife (Leica). The transverse sections were stained in $0.05 \%$ toluidin blue $\mathrm{O}$ in acetate buffer ( $\mathrm{pH} 4.4$ ) (Feder; O'Brien, 1968) for 5 min. Trichomes were isolated, clarified with $\mathrm{NaOCl}$ $2 \%$ diluted in water $1: 8(\mathrm{v}: \mathrm{v})$, washed in water and stained in safranin 1\% in ethanol 50\% (Johansen, 1940) and observed at covered glass sheet in an Olympus BH2 microscope coupled to an Olympus C-35AD4 camera.

\section{Macromolecular analysis}

DNA extraction: DNA was extracted from all specimens but Xavier Chaves (Table 1) using CTAB protocol (Ferreira and Grattapaglia, 1998).

ITS analysis: The ITS region was amplified using the primers ITS4(5'-TCCTCCGCTTATTGATATGC-3'), primer designed by Hsiao et al. (1994) and ITSleu1 (5'-GTCCACTGAACCTTATCATTTAG-3'), primer described by Bohs and Olmstead (2001), anchored, respectively, in the conserved ends of $18 \mathrm{~S}$ and $26 \mathrm{~S}$ ribosomal genes. PCR amplification was undertaken in a final volume of $10 \mu \mathrm{L}$ consisting of: $1-10 \mathrm{ng}$ of DNA, buffer $\left(1.5 \mathrm{mM} \mathrm{MgCl}_{2}, 50 \mathrm{mM} \mathrm{KCl}, 10 \mathrm{mM}\right.$ Tris$\mathrm{HCl}, \mathrm{pH} 8.5), 200 \mu \mathrm{M}$ each dNTP, $0.5 \mathrm{U}$ of Taq DNA polymerase, 5.0 pmol of each primer. The reactions were covered with a drop of mineral oil and subjected to the following cycle program: initial denaturation step for $3 \mathrm{~min}$ at $95^{\circ} \mathrm{C}$, and then 32 cycles as follows: annealing at $58{ }^{\circ} \mathrm{C}$ for $1 \mathrm{~min}$, extension at $72{ }^{\circ} \mathrm{C}$ for 2 min, denaturation at $95^{\circ} \mathrm{C}$ for $45 \mathrm{~s}$ and a final extension step at $72^{\circ} \mathrm{C}$ for $5 \mathrm{~min}$.

Cloning and sequencing of PCR products: PCR products of the three specimens cited above were cloned using a pCR-II TOPO kit and transformed into quimiocompetent TOP10 Escherichia coli, according to manufacturer's instructions (Invitrogen). Plasmides were isolated using the Quiagen plasmid miniprep kits according to the manufacturer's protocol. Sequencing of ITS of rDNA were carried out using a Kit DYEnamic ET dye terminator MegaBace (Amersham). Such products were processed in a DNA automated sequencer MegaBace 500 DNA Analysis System (Amersham Pharmacia Biotech).

Sequence Analysis: Confirmation of the sequences as target regions was undertaken through the search software BLASTn (NCBI). Afterwards, complete sequences were aligned by the software Clustal W (Thompson et al., 1994) using the Bioedit software (http://jwbrown.mbio.ncsu.edu/BioEdit/bioedit.html).

\section{Micromolecular analysis}


Plant extraction: The plant leaves (Table 1) were oven dried at $40{ }^{\circ} \mathrm{C}$ and powdered at Janke and Kunkel A10 analytical mill and extracted with the mixture of ethyl acetate, methanol and water (10:4:1), at room temperature.

Chromatography: From each extract, $100 \mathrm{mg}$ were applied on silica gel plates Merck $60 \mathrm{~F}_{254}$. The same extraction solvent mixture was used as mobile phase. After elution, the plates were observed under $\mathrm{UV}_{254 \mathrm{~mm}}$ and $\mathrm{UV}_{366 \mathrm{~mm}}$ and sprayed with Dragendorff and Natural Product reagent (Wagner; Bladt, 1996) for spots detection. Analytical HPLC were run in a Shimadzu chromatographer with LC-10AD pump coupled to a SPD-M10A detector with photodiodo array. Shimpack prep ODS ( $4.6 \times 250 \mathrm{~mm}, 7 \mathrm{mM})$ column was eluted with methanol $50 \%$ at $1 \mathrm{~mL} / \mathrm{min}$ flow rate. Each injection was run with $20 \mathrm{~mL}$ of extract in methanol solution $(1 \mathrm{mg} /$ $\mathrm{mL}$ ). Semi-preparative column was run on a Shodex column eluted with $100 \%$ methanol.

Structural elucidation: $\mathrm{NMR}^{1} \mathrm{H}$ and ${ }^{13} \mathrm{C}, \mathrm{COSY}$, DEPT, HMQC and HMBC were run on a Brucker DX-400 spectrometer and samples dissolved in $\mathrm{CD}_{3} \mathrm{OD}$. Mass spectra were obtained in a ThermoFinnigan quadrupolo ion trap mass spectrometer model LCQ Advantage with electrospray ion source at positive and negative mode.

\section{RESULTS AND DISCUSSION}

Solanum cernuum can be easily identified when entire leaves of the species are commercialized. The leaves are simple, oblong or elliptic, with entire or repand margin, unarmed, discolored, 21.0 to 32.6 $\mathrm{cm}$ long, 6.3 to $18.4 \mathrm{~cm}$ wide, obtuse or acute at the apex, asymmetric at the base, adaxial surface densely tomentose with prominent venation, abaxial surface sparsely tomentose, petiole 3.2 to $6.9 \mathrm{~cm}$ long, slightly winged.

However, when the leaves are not entire, other markers are necessary. In this regarding we also prospect anatomical and macromolecular markers.

Previous work on anatomy established that in Solanum the trichomes are very diverse in shape and size (Edmonds, 1982). Some of these structures are restrict to one species, and can be used to distinguish subgenera, sections (Seithe; Anderson 1982) and groups of Solanum (Mentz et al., 2000), while others are quite common (Siddiqi et al., 1980).

In this research, the trichomes of Solanum cernuum were nominated according to Roe (1971). No different trichomes from those already described for the genus was found. However, the results suggest that the set of trichomes described below are exclusive of $S$. cernuum and S. castaneum Carvalho (Carvalho, 1996). This set is composed by: glandular trichomes shortly pedicellate, unisseriated with four or more apical cells (found exclusively on leaf surfaces -Fig 1); porrectstellate (leaf lamina, petiole, and fruit surface -Fig 2); stellate plurisseriated short pedicellate (most are brown, found at leaf lamina, petiole, and fruit surface -Fig 3 and 4); dendroid stelliform (stems, petioles, pedicels, and ovary - Fig 5); paleous (stems, pedicels and the external face of the calyx, and scarce in petioles - Fig 6 and 7). Carvalho (1996) defined this type of trichomes as emergencies, however Siddiqi et al. (1980) classified the paleous dentritic trichomes, not as emergencies, since they are constituted just of epidermal tissues, whereas emergencies are also formed of subepidermal tissues. In fact, a subepidermal layer was not observed in the paleous trichomes of S. cernuum (Fig 8).

In general, the trichomes of Solanum cernuum were found in great quantity in all the observed organs. On leaves, the stellate indument may be constituted of 1 to 3 strata in the abaxial surface. No trichomes were observed on stigmas, styles, filaments and anthers.

The sequencing of nucleotides of DNA has been proposed as a DNA barcode of the organisms (Blaxter, 2003). As macromolecular markers of $S$. cernuum we found that for DNA extraction the protocol CTAB was the most satisfactory. The nucleotides sequences obtained using PCR technique were confirmed as the target region (ITS1, 5.8S and ITS2) after comparison and alignment with the sequences of genes deposited at GenBank. Within these sequences we highlight the species Solanum exiguum (AY523893), with $36.4 \%$ of adenine and timine (AT) and Solanum diversifolium (AY523892), with $35.1 \%$ of AT. We found that in $S$. cernuum this region is constituted by approximately 600 bases pairs, being $48.1 \%$ AT. This sequence determined for S. cernuum was deposited at GenBank under the accession number DQ837371.

Besides the morphological, anatomical and macromolecular markers, we also prospected micromolecular markers that could be useful, also, if the plant is found as crude extract.

The crude extracts were obtained as described in the experimental section and yielded $4.4 \%$ to $10.5 \%$ $(x=7.53$ and $\mathrm{sx}=1.95)$ in relation to the plant powder. This result is not related to seasonality.

TLC analysis displayed several spots, after sprayed with Dragendorff reagent, from which four with $\mathrm{Rf}=0.30$; $0.46 ; 0.61 ; 0.66$ (Fig 9). The first three were orange and the last one was gray. This profile can be used carefully as marker once all but one extract presented at least three of these spots.

HPLC chromatograms showed peaks at 4.00 , $5.42,6.59$ and $9.01 \mathrm{~min}$ with variable areas. The chromatograms were different from those obtained from extracts of Solanum esculentum, Bauhinia curvula and Ocimum gratissimum. These species were chosen randomly as control once there is no report on literature of possible adulteration of $S$. cernuum. Using semi-prep HPLC followed by filtration on Sephadex LH-20 in methanol, the compounds with $\mathrm{Rf}=0.61$ and 0.66 where isolated (Fig 10). The analysis of their spectral data 
together with data published in literature (Matthes et al., 1980; Agrawal, 1989; Markham; Ternai, 1976) allowed us to identify them as quercitrin and afzelin, respectively. Flavonol glycosides are frequent in the genus Solanum, mostly derived from kampferol and quercetin (Silva et al., 2003). Quercitrin, a 3-O- $\alpha$-L-rhamnospyranosil from quercetin was previously isolated from Solanum melongena (Barnabas; Nagarajan, 1989). This is the first report of the occurrence of afzelin in Solanaceae.

\section{CONCLUSION}

The whole leaves of Solanum cernuum can be identified using morphological data. When leaves are not entire, the presence of the set of trichomes described for this species can be used as anatomical markers. However, when the plant material is powdered, it is necessary to investigate the chromatography profile of its crude extract. Afzelin together with quercitrin were isolated as micromolecular markers. The eletrophoretic profile of the entire ITS regions of the rDNA of $S$. cernuum without a pre-treatment with restriction enzymes cannot be used as marker for the species. The determination of the sequence of nucleotides of the region ITS 1, 5.8S and ITS 2 of $S$. cernuum published here will support the development of RFLP conditions in order to obtain an eletrophoretic profile useful as macromolecular markers. These macromolecular markers should be used for $S$. cernuum identification when other markers would not be possible.

\section{ACKNOWLEDGMENTS}

Fiocruz, Fapemig, CNPq and Capes for the financial support.

\section{REFERENCES}

Agrawal PK 1989. Carbon-13 NMR of flavonoids. Amsterdam, Elsevier Science Publishers.

Baldwin BG, Sanderson MJ, Porter JM, Wojciechowski MF, Campbell CS, Donoghue MJ 1995. The ITS region of nuclear ribosomal DNA - a valuable source of evidence on Angiospem phylogeny. Ann Mo Bot Gard 82: 247-277.

Barbosa-Filho JM, Agra MF, Oliveira RAG, Paulo MQ, Trolin G, Cunha EVL, Ataide JR, Bhattacharyya J 1991. Chemical and pharmacological investigation of Solanum species of Brazil - A search for solasodine and other potentially useful therapeutic agents. Mem I Oswaldo Cruz 86: 189-191.

Barnabas CGG, Nagarajan S 1989. Chemical and pharmacological studies on the leaves of Solanum melongena. Fitoterapia 60: 77-78.

Blaxter ML 2003. Counting angels with DNA. Nature 421: 122-124.

Bohs L, Olmstead RG 2001. A reassessment of Normania and Triguera (Solanaceae). Plant Syst Evol 228: 33-48.

Borse BB, Rao LJM, Nagalakshmi S, Krishnamurthy N 2002. Fingerprint of black teas from Índia: identification of the regio-specific characteristics. Food Chem 79: 419-424.

Bridson D, Forman L 1992. The herbarium handbook. Kew Royal Botanic Gardens, London.

Carvalho LDF 1989. Espécies de Solanum (Seção Cernuum

Table 1. Collection data of the four specimens of Solanum cenuum and the three other species used as controls and the extract samples for TLC plate.

\begin{tabular}{|c|c|c|c|c|c|}
\hline Family & Species & Locality & Date & Voucher & ${ }^{\mathrm{a}} \mathrm{TLC}$ \\
\hline \multirow[t]{10}{*}{ Solanaceae } & \multirow[t]{9}{*}{ Solanum cernuиm Vell. } & \multirow[t]{2}{*}{ Xavier Chaves } & Oct/1998 & & 1 \\
\hline & & & Dec/1999 & & 2 \\
\hline & & \multirow[t]{2}{*}{ Moeda } & May/1998 & BHCB 42855 & 3 \\
\hline & & & $\mathrm{Dec} / 1999$ & & 4 \\
\hline & & \multirow{2}{*}{$\begin{array}{l}\text { Belo Horizonte } \\
{ }^{\text {}} \text { ICB- UFMG }\end{array}$} & $\mathrm{Feb} / 2000$ & & 5 \\
\hline & & & Aug/1998 & & 6 \\
\hline & & \multirow{3}{*}{$\begin{array}{l}\text { Belo Horizonte } \\
{ }^{c} \text { EE- UFMG }\end{array}$} & Oct/1998 & BHCB 16886 & 7 \\
\hline & & & Jul/1999 & & 8 \\
\hline & & & $\mathrm{Feb} / 2000$ & & 9 \\
\hline & Solanum lycopersicum L. & Belo Horizonte & $\mathrm{Feb} / 2000$ & BHCB 56348 & 10 \\
\hline Fabaceae & Bauhinia curvula Benth. & Pedro Leopoldo & Mar/1996 & PAMG 45207 & 11 \\
\hline Lamiaceae & Ocimum gratissimum L. & Belo Horizonte & $\mathrm{Jul} / 1995$ & BHZB 2106 & 12 \\
\hline
\end{tabular}

All localities belong to the State of Minas Gerais. a) Spot number at thin layer chromatogram; b) Instituto de Ciências Biológicas, Universidade Federal de Minas Gerais; c) Estação Ecológica da Universidade Federal de Minas Gerais. 

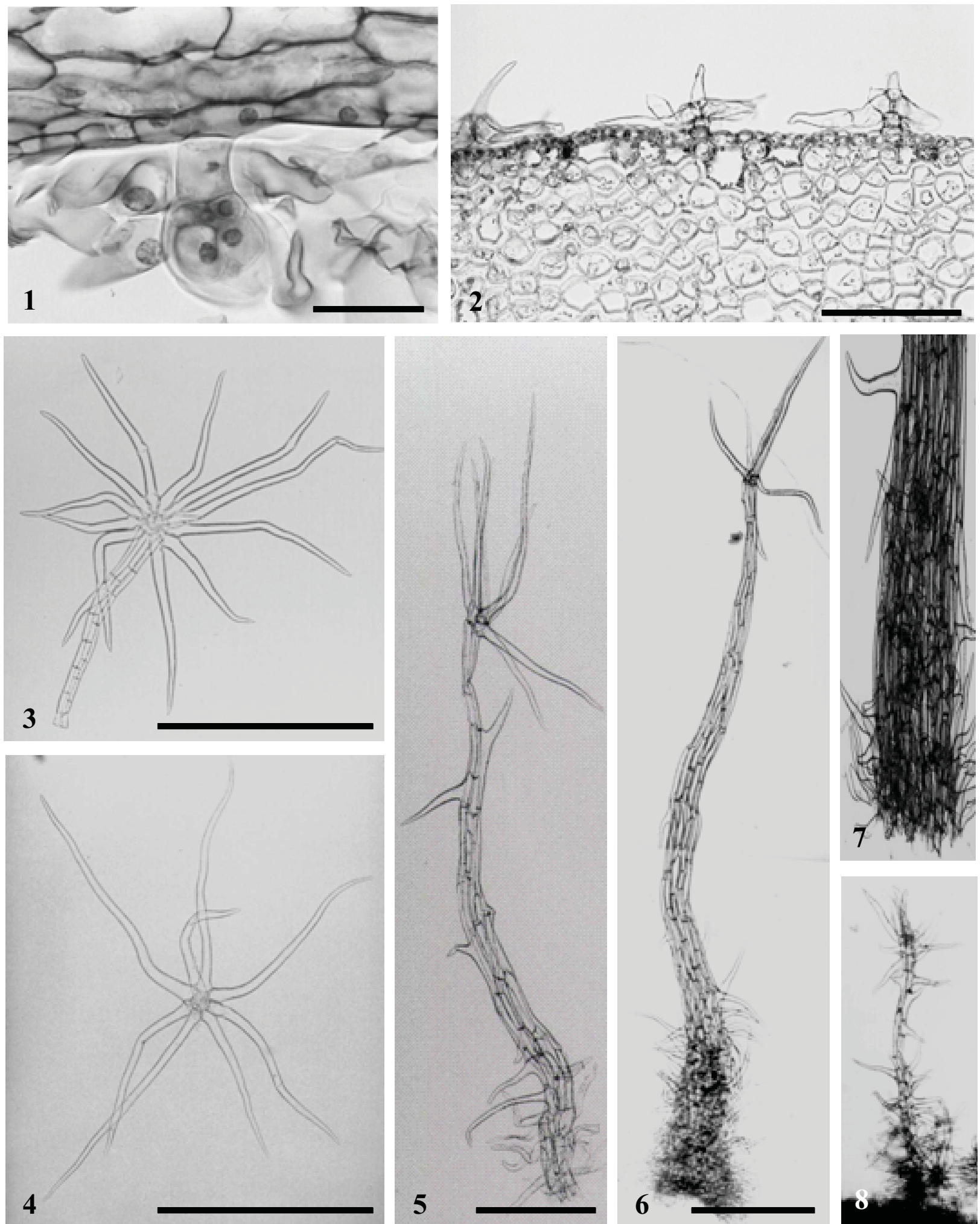

Figure 1 - 8. Types of trichomes found on Solanum cernuum Vell. leaves. 1 - Glandular trichome; 4-celled head; uniseriated stalk $($ scale bar $=10 \mu \mathrm{m}) .2$ - Porrect trichome; free hand sections with no dye or reagent (scale bar $=50 \mu \mathrm{m}) .3$ - Stellate short-stalked trichome, with no dye or reagent; frontal view; a - stalk; b- lateral rays (scale bar $=50 \mu \mathrm{m}$ ). 4 - Stellate short-stalked trichome, with no dye or reagent; top view (scale bar $=50 \mu \mathrm{m}) .5$ - Dendritic trichome from the peduncle of the inflorescence $(\mathrm{scale}$ bar $=50 \mu \mathrm{m})$. 6 - Chaffy-like trichome (scale bar $=50 \mu \mathrm{m}) .7$ - Base of the chaffy-like trichome $($ scale bar $=50 \mu \mathrm{m}) .8$ - Dendritic trichome of the peduncle of the inflorescence $($ scale bar $=50 \mu \mathrm{m})$. 8- Dendritic trichome of the peduncle of the inflorescence $(\mathrm{scale} b a r=50 \mu \mathrm{m})$. 


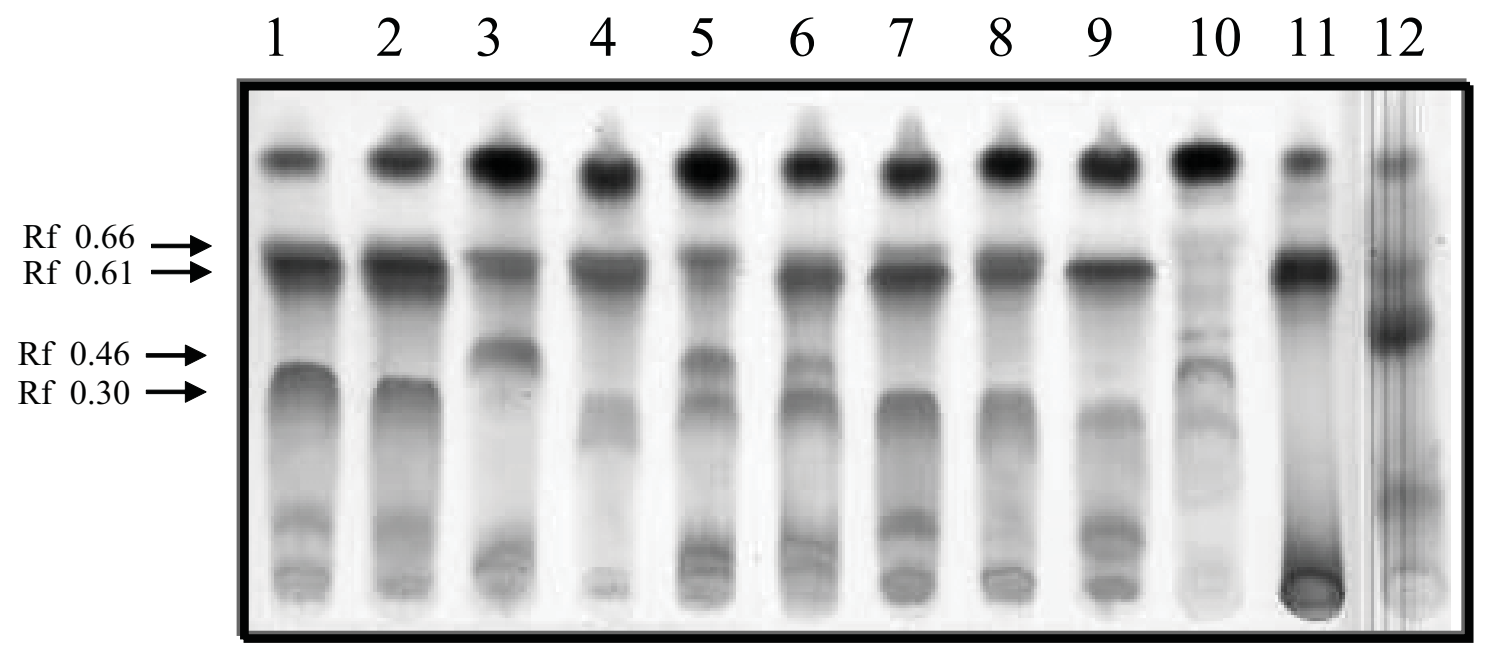

Figure 9. TLC profile of the crude extracts from leaves of Solanum cernuum. Merck 60F Silicagel plate; mobile phase: ethyl acetate/methanol/water (10:4:1); developed with Dragendorff reagent and $\mathrm{NaNO}_{3}(10 \%)$. 1-9: samples of S. cernuum 10: Solanum esculentum; 11: Bauhinia curvula; 12: Ocimum gratissimum.

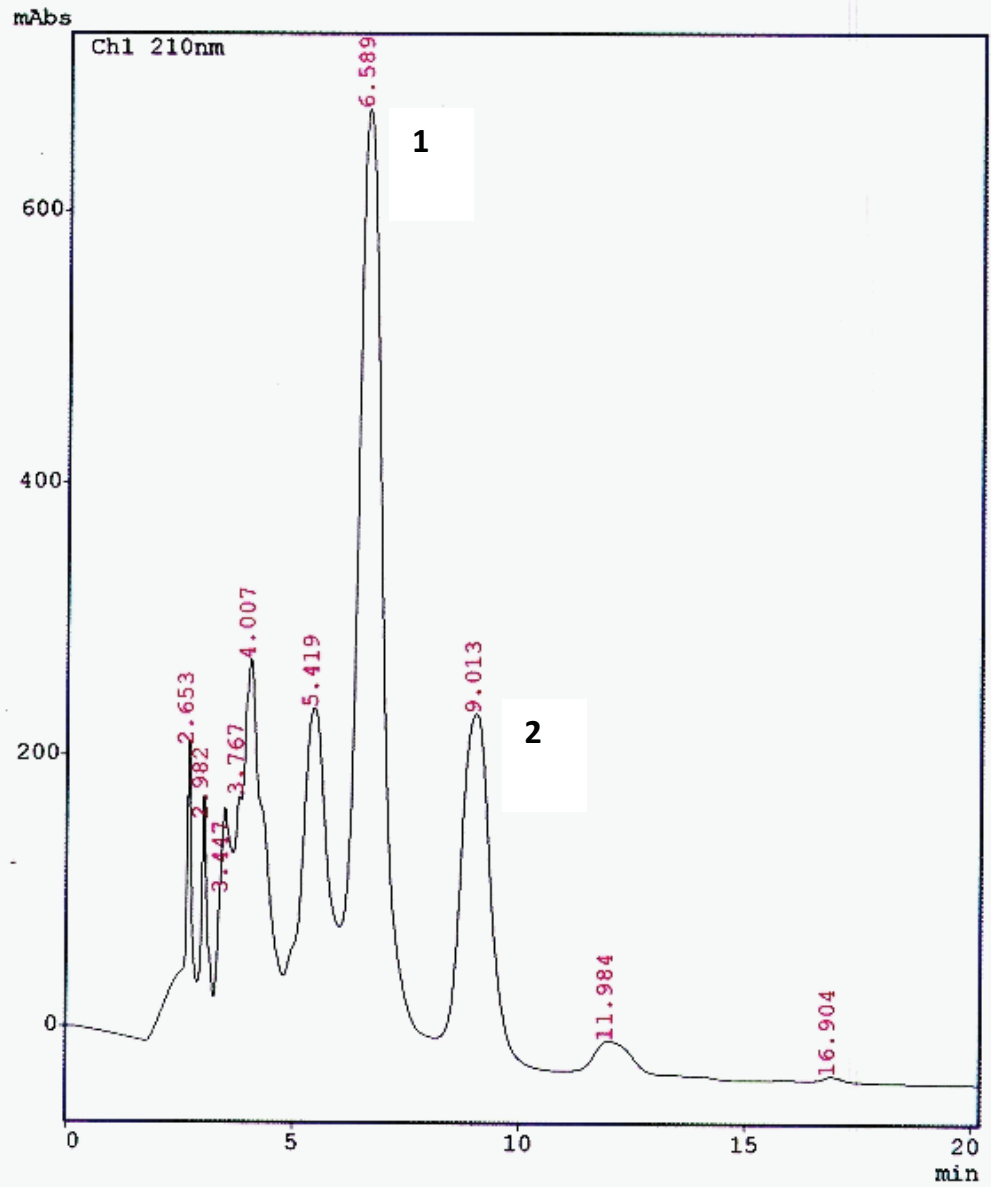

Figure 10. LC-UV profile of crude extract from leaves of Solanum cernuum); column Shimpak ODS (4.6 x 250mm); methanol $50 \%$ as mobile phase with flow rate $1 \mathrm{ml} / \mathrm{min}$; Detection at $1_{210} \mathrm{~nm}$. 1- quercitrin; 2- afzelin. 
e Lepidotum) usadas na medicina popular brasileira. Rev Bras Farm 70: 7-10.

Carvalho LDF 1995. Aspectos fitogeográficos das espécies de Solanum seção Cernuum e Lepidotum (Solanaceae). Cadernos de Geociências 13: 39-46.

Carvalho, LDF 1996. Especies de Solanum das seções Cernuum Carv. et Sheph. e Lepidotum (Dun.) Seithe V. Hoff. (Solanaceae). Pesquisas 46: 5-83.

Di X, Chan KKC, Leung HW, Huie CW 2003. Fingerprint profiling of acid hydrolyzates of polysaccharides extracted from the fruiting bodies and spores of Lingzhi by high-performance-thin-layer chromatography. J Chromatogr A 1018: 85-95.

Edmonds JM 1982. Epidermal hair morphology in Solanum L. section Solanum. Bot J Linn Soc 85: 153-167.

Fan XH, Cheng YY, Ye ZL, Lin RC, Qian ZZ 2006. Multiple chromatographic fingerprinting and its application to the quality control of herbal medicines. Anal Chim Acta 555: 217-224.

Feder N, O'Brien TP 1968. Plant microtechnique: some principles and new methods. Am J Bot 55: 123-142.

Ferreira ME, Grattapaglia D 1998. Introdução ao uso de marcadores moleculares em análise genética. EMBRAPA, Brasília, 220 p.

Hostettmann K, Marston A 2002. Twenty years of research into medicinal plants: results and perspectives. Phytochem Rev 1: 275-285.

Hsiao C, Chatterton NJ, Asay KH, Jensen KB 1994. Phylogenetic relationships of 10 grass species: an assessment of phylogenetic utility of the internal transcribed spacer region in nuclear ribosomal DNA in monocots. Genome 37: 112-120.

Hunziker AT 2001. The genera of Solanaceae. A.R.G. Gantner Verlag K. G, Ruggell, 500pp.

Johansen DA 1940. Plant microtechnique. McGraw Book, New York, 523pp.

Joshi K, Chavan P, Warude D, Patwardhan B 2004. Molecular markers in herbal drug technology. Curr Sci 87: 159-165.

Markham KR, Ternai B $1976 .{ }^{13} \mathrm{C}$ NMR of flavonoides - II Flavonoids other then flavone and flavonol aglycones. Tetrahedron 32: 2607-2612

Matthes HWD, Luu B, Ourisson G 1980. Cytotoxic components of Zingiber zerumbet, Curcuma zedoaria and C. domestica. Phytochemistry 19: 2643-2650.

Mentz LA, Oliveira PL, Silva MV 2000. Tipologia dos tricomas das espécies do gênero Solanum (Solanaceae) na região Sul do Brasil. Iheringia 54: 75-106.

Roe KE 1971. Terminology of hairs in the genus Solanum. Taxon 20: 501-508.

Seithe A, Anderson GJ 1982. Hair morphology and the relationships of species in Solanum sect. Basarthrum. Plant Syst Evol 139: 229-258.

Silva TMS, Carvalho MG, Braz-Filho R, Agra MF 2003. Ocorrência de flavonas, flavonóis e seus glicosíseos em espécies do gênero Solanum (Solanaceae) Quim Nova 26: 517-522.

Silva TMS, Agra MF, Bhattacharyya J 2005 Studies on the alkaloids of Solanum of northeastern Brazil. Rev Bras Farmacogn 15: 292-293.

Siddiqi SA, Ahmad R, Sidiqui SP 1980. Studies on the structure and ontogeny of stomata and trichomes on the leaves of some Solanum species. Geophytology
10: 188-192.

Takagi K, Toyoda M, Shimizu M, Satoh T, Saito Y 1994. Determination of tomatine in foods by liquid chromatography after derivatization. $J$ Chromatogr A 659: 127-131.

Thompson JD, Higgins DG, Gilson TJ 1994. Clustal W: improving the sensitivity of progressive multiple sequence alignment through sequence weighting, position-specific gap penalties and weight matrix choice. Nucl Acids Res 22: 4673-4680.

Wagner H, Bladt S 1996. Plant drug analysis, a thin layer chromatography atlas. $2^{\text {nd }}$ Edition. Berlin: SpringerVerlag, p.360-362.

Yang Z 2006. Online hyphenated liquid chromatographynuclear magnetic resonance spectroscopy-mass spectrometry for drug metabolite and nature product analysis. J Pharm Biomed Anal 40: 516-527.

Yencho GC, Kowalski SP, Kobayashi RS, Sinden SL, Bonierbale MW, Deahl KL 1998. QTL mapping of foliar glycoalkaloid aglycones in Solanum tuberosum $\mathrm{x} S$. berthaultii potato progenies: quantitative variation and plant secondary metabolism. Theor Appl Genet 97: 563-574.

Zhao ZL, Zhou KY, Dong H, Xu LS 2001. Characters of nrDNA ITS region sequences of fruits of Alpinia galanga and their adulterants. Planta Med 67: 381-383. 